\title{
Birth Trauma: Sphincter Injuries
}

\section{Doğum Travması: Sfinkter Yaralanması}

\author{
(1) Murat Çakır, (1) Mehmet Aykut Yıldııım \\ Necmettin Erbakan University, Meram Faculty of Medicine, Department of General Surgery, Konya, Turkey
}

\section{IIIIIIII ABSTRACT}

Aim: Fecal incontinence is a condition that has social and economic effects and that disrupts the quality of life. A complete definition of fecal incontinence is difficult. However, it can be defined as the failure to control the anal discharge of intestinal content at an appropriate time and place. The diagnosis of fecal incontinence is challenging and complex. One of the most important causes of fecal incontinence is trauma in the perianal region. The most important cause of such trauma is birth trauma. We examined our cases who had sphincter repair due to acute injury in the perianal region during delivery.

Method: The data of 10 female patients who were admitted to Necmettin Erbakan University, Meram Faculty of Medicine, Department of General Surgery with perianal injuries between 2010 and 2015 were analyzed retrospectively. Data regarding age, severity of injury, first intervention time, repair type, wound problems and post-operative complications were investigated. Long-term results were analyzed.

Results: It was observed that 10 female patients underwent emergency surgery due to acute perianal injury. Tenpatients were included in the study and their files were analyzed retrospectively. The mean age of the patients was 24 (range: 19-36) years. Four patients had type 4 injury, two had type 3a injury, one had type $3 \mathrm{~b}$ injury, and three had type $3 \mathrm{c}$ injury.

Conclusion: We believe that it is important to perform surgical treatment before tissue edema develops.

Keywords: Childbirth, incontinence, trauma

\section{|IIIIIII|| ÖZ}

Amaç: Fekal inkontinans sosyal ve ekonomik etkileri olan ve yaşam kalitesini bozan bir durumdur. Fekal inkontinansın tam bir tanımını yapmak zordur. Ancak barsak içeriğinin uygun zaman ve yerde, anal yoldan çıkışının kontrol edilememesi şeklinde tanımlanabilir. Fekal inkotinans tanısı zor ve karmaşıktır. Fekal inkontinansın en önemli nedenlerinden biri perianal bölgede oluşan travmadır. Bu travmanın en önemli nedeni doğum travmasıdır. Doğum esnasında perianal bölgede oluşan akut yaralanma nedeniyle sfinkter tamiri yapılan olgularımızı inceledik.

Yöntem: Necmettin Erbakan Üniversitesi Meram Tıp Fakültesi Genel Cerrahi Kliniği 2010-2015 yılları arasında başvuran perianal bölge yaralanması olan 10 kadın hastanın verileri retrospektif olarak incelendi. Hastaların yaş, yaralanma derecesi, ilk müdahale zamanı, onarım şekli, yara problemleri ve postoperatif komplikasyonları değerlendirildi. Uzun dönem sonuçları incelendi.

Bulgular: On kadın hastanın akut perinal bölge yaralanması nedeniyle acil cerrahi uygulandığı tespit edildi. Çalışmaya 10 hasta alındı ve dosyaları retrospektif olarak incelendi. Kadın hastalarının yaş ortalaması 24 (19-36) idi. Kadın hastaların 4'ünde tip 4 yaralanma, 2'sinde tip 3a, 1'inde tip 3b ve 3'ünde tip 3c yaralanma izlendi.

Sonuç: Cerrahi müdahalenin doku ödemi gelişmeden yapılmasının önemli olduğu kanaatindeyiz.

Anahtar Kelimeler: Doğum, inkontinans, travma

\section{Introduction}

Fecal incontinence is a condition that has social and economic effects and disrupts quality of life. ${ }^{1}$ It is hard to offer an exact definition of fecal incontinence. However, it can be defined as the failure to control the anal discharge of intestinal content at an appropriate time and place. $^{2}$ The prevalence, diagnosis, and treatment methods of fecal incontinence could not be clearly identified. Many methods used in diagnosis and treatment have evolved over time. ${ }^{3}$ The

Address for Correspondence/Yazışma Adresi: Mehmet Aykut Yıldırım MD,

Necmettin Erbakan University, Meram Faculty of Medicine, Department of General Surgery, Konya, Turkey

E-mail: drmayildirim@hotmail.com ORCID ID: orcid.org/0000-0001-9580-6004

Received/Gelis Tarihi: 31.12.2018 Accepted/Kabul Tarihi: 03.02.2019

${ }^{\circ}$ Copyright 2019 by Turkish Society of Colon and Rectal Surgery

Turkish Journal of Colorectal Disease published by Galenos Publishing House. 
diagnosis of fecal incontinence is challenging and complex. One of the most significant causes of fecal incontinence is trauma in the perianal region. The most important cause of such trauma is birth trauma. It is difficult to evaluate patients and to plan treatment. The surgical method is determined by the severity of sphincter damage and injury to organs in the perianal region. Therefore, the aim of this study was to analyze the patients who underwent sphincter repair due to acute injuries in the perianal region.

\section{Materials and Methods}

The data of 10 female patients who were admitted to Necmettin Erbakan University, Meram Faculty of Medicine, Department of General Surgery with perianal injuries between 2010 and 2015 were analyzed retrospectively. Data regarding age, severity of injury, first intervention time, repair type, wound problems and post-operative complications were investigated. Long-term results were analyzed. Patients with acute injury requiring emergency intervention were included in the study. Patients who did not underwent emergency intervention for a reasonbut who underwent repair procedures in the long-term were excluded from the study.

\section{Results}

It was observed that 10 patients underwent emergency surgery due to acute perianal injury. It was determined that 10 patients experienced injury during childbirth. Ten patients were included in the study and their files were analyzed retrospectively. The mean age of the patients was 24 (range: 19-36) years. Four patients had type 4 injury, two had type $3 \mathrm{a}$ injury, one had type $3 \mathrm{~b}$ injury, and $3 \mathrm{had}$ type

Table 1. Patient data

$\begin{array}{ll}\text { Variable } & 10 \\ \text { Number } & 24(19-36) \\ \text { Age, years } & \text { Type } 4(\mathrm{n}=4) \\ & \text { Type } 3 \mathrm{a}(\mathrm{n}=2) \\ \text { Severity of injury } & \text { Type } 3 \mathrm{~b}(\mathrm{n}=1) \\ & \text { Type 3c (n=3) } \\ \text { Pre-operative time } & 10(1-18) \text { hour }(\mathrm{n}=1,3 \text { day }) \\ \text { Postoperative follow-up time } & 3(1-7) \text { years } \\ \text { Mean resting pressure } & 40(30-70) \mathrm{mmHg} \\ \text { Mean extrusion pressure } & 60(50-120) \mathrm{mmHg} \\ \text { Mean duration of extrusion } & 30(20-56) \text { seconds } \\ \text { Mean coughing reflex } & 70(54-110) \mathrm{mmHg}\end{array}$

3c injury (Figure 1). Six patients were primipares and six patients gave birth to babies weighing more than 4000 gr. Six patients had episiotomy and 3 did not receive episiotomy. Moreover, six of the patients had vacuum assisted labor. Nine of the patients had emergency intervention within the first 10 (range: 1-18) hours. One patient was initially treated at an external center and presented to our center on the $3^{\text {rd }}$ day upon split formation in the injury. This patient was reoperated (Table 1).

While all patients received sphincteroplasty and vaginoplasty, five patients underwent levatorplasty. After repair, the rectovaginal septum was thicker than $2 \mathrm{~cm}$ in all patients. Three/ 0 polyglactin sutures were used for all repairs and interrupted repair was completed (Figure 2). Drains were placed in the repair area. Vaginal tampons were used and were frequently changed to reduce the risk of surgical site complications. Colorectal irrigation was performed in all patients during the surgical procedure.

Colostomy was not created for any patient, however, medical ileus was created. Parenteral feeding was continued for six days. All patients received third generation cephalosporin and metronidazole. Oral intake was enabled on the $5^{\text {th }}$ day and the patients were discharged between the $7^{\text {th }}$ and $10^{\text {th }}$ days. Patients were asked to avoid sexual intercourse for 3 months. They were advised not to undergo vaginal delivery in their following labors. All patients received laxatives in

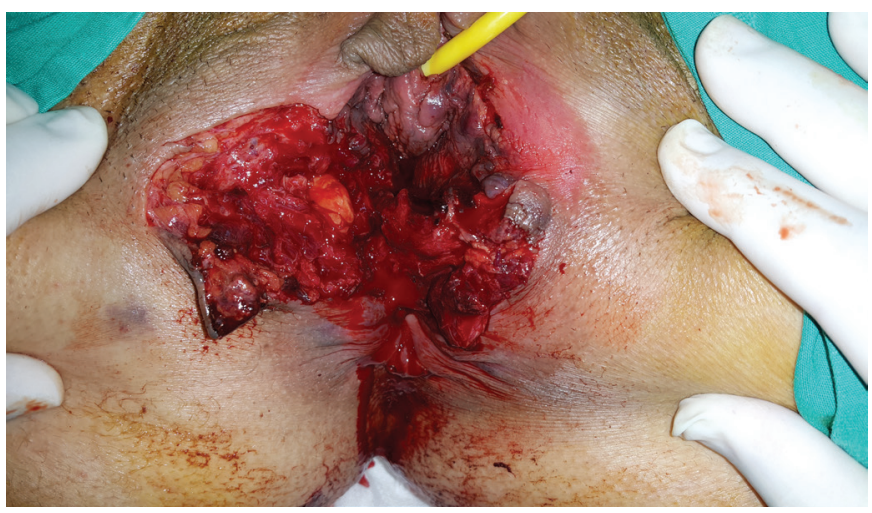

Figure 1. A patients with type 3c injury

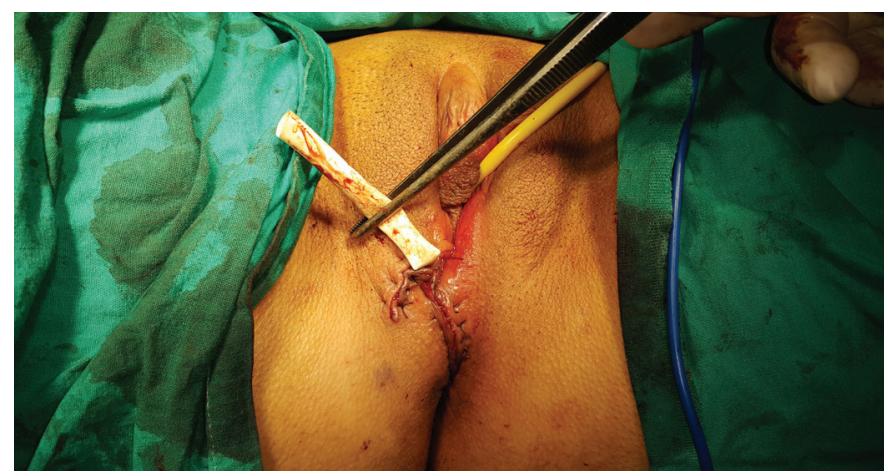

Figure 2. Post-repair image 
order to ease stool discharge and to prevent constipation for a month. This period was extended in patients with chronic constipation.

All patients were followed-up for one month. None of the patients had wound site pathologies. Anal manometric pressure measurements were conducted at the $3^{\text {rd }}$ month. The mean resting pressure was 40 (range: $30-70$ ) $\mathrm{mmHg}$, extrusion pressure was 60 (range: $50-120) \mathrm{mmHg}$, mean duration of extrusion was 30 (range: 20-56) seconds, and coughing reflex was 70 (range: $54-110$ ) $\mathrm{mmHg}$.

Three patients experienced gas incontinence at the $6^{\text {th }}$ month. These patients received biofeedback for 2 months upon failure to detect complete sphincter damage by imaging techniques. Complaints of the patients improved after two months. The patients have been in the follow-up program for a mean period of 3 years and they do not have complaints of incontinence.

\section{Discussion}

The main causes of the problem in most of the patients with fecal incontinence are obstetric trauma or sphincter defects that emerge after anal surgery. There are varying degrees of injury in 53\% to $79 \%$ of patients following vaginal delivery. ${ }^{4,5}$ Although the rate of such injuries is too high, not all injuries cause sphincter damage. The rate of primary obstetric anal sphincter injury is approximately $18 \%$ in vaginal deliveries. ${ }^{6}$ Eight studies were investigated in a meta-analysis and it was seen that $5.7 \%$ of women had anal sphincter injury during first labor and $6.3 \%$ during the following labors. ${ }^{7}$ In another study, a total of 700 patients pregnant with twins were evaluated and the rate of sphincter injury was found to be $2.8 \% .{ }^{8}$ In a study of patients who had vaginal or C-section deliveries, the authors found that complaints related to incontinence varied between 13\% and $25 \% .{ }^{9}$ The rate of fecal incontinence in patients with postpartum sphincter injury is approximately $7.7 \% .{ }^{10}$ While the rate of incontinence is $6.3 \%$ in nulliparous women, it is $8.8 \%$ in uniparous women and $8.4 \%$ in secundiparous women, compared with $11.5 \%$ in triparous women and women who had more than 3 deliveries. ${ }^{11}$ Only 27\% of endoanal ultrasonography results show occult anal sphincter injuries. ${ }^{12}$ One third of the patients with detected damage also had symptoms of incontinence. Asymptomatic patients are at risk for incontinence in the coming years. All of our patients had anal sphincter damage due to birth trauma. The vast majority of our cases sustained anal sphincter injury during the first delivery.

Creation of episiotomy during labor prevents uncontrolled perianal fissures. However, the results of a meta-analys is revealed that episiotomy increased the risk of fecal incontinence. ${ }^{13}$ The most important parameters for sphincter damage at vaginal delivery are interventional delivery and birthweight of the baby. ${ }^{14}$ Tertiary fissures are frequently seen in interventional deliveries with midline episiotomy. Uncontrolled fissures are less common after mediolateral episiotomy procedures. Although six patients had episiotomy, uncontrolled fissures could not be prevented. We believe this was due to the problematic timing of episiotomy. Although the starting point of the episioincision was medio-lateral, it then proceeded medially. Six patients had interventional deliveries. Six of the babies had a birth weight of more than 4000 grams.

The first treatment that should be offered for any incontinence patient with anal sphincter defect is primary sphincter repair. Pre-operative intestinal cleaning should be done very carefully. Perioperative antibiotic prophylaxis is necessary. Randomized controlled studies have demonstrated that prophylaxis with second-generation cephalosporin significantly reduces the rate of infection. ${ }^{15}$ Infection rates following anal sphincter repair due to vaginal birth injury is as high as $20 \%$, whereas, wound healing problems reach up to $25 \% .{ }^{16}$ Surgical site infection was not observed in any of our patients. We administer a combination of third generation cephalosporin and metronidazole prophylaxis, and we continue treatment for 3 days. We pay special attention to keep the vagina dry. We believe that the reason why we do not have complications such as wound site infection and wound splitting is the attention we pay.

The vaginal wall on the front and anal canal mucosa on the back should be repaired in internal and external sphincter procedures. Sphincter repairs can be done in end-to-end or overlapping forms. The difference between end-to-end and overlapping suturing has not been shown in the literature within one-year of follow-ups. ${ }^{17}$ We do end-to-end repair in cases with early surgery following injury. We prefer the overlapping method more for chronic cases. We repair all layers separately with interrupted sutures.

There is no sufficient data on whether a patient who had vaginal injury following vaginal delivery should have her next deliveries by vaginal or C-section delivery. However, some studies have reported that the possibility of a new anal sphincter injury following vaginal delivery is $3 \%{ }^{18}$ Nevertheless, we do not recommend vaginal delivery to our patients. These patients have lower anal manometric pressure than normal patients (although the measurements do not have standard values). Micro or macro sphincter injuries happen in all deliveries. We support the idea that patients should not be exposed to the risk of having possible injuries.

Incontinence can be seen in women with sphincter injuries during delivery after repair. The most important cause of this 
is residual anterior sphincter defects. ${ }^{3}$ Adequate continence might not be achieved in the long term by the primary repair of third and fourth degree sphincter fissures that form during delivery. The incidence of anal incontinence was reported as $15-61 \%$, although primary repair is done during delivery. The endoanal ultrasonography results presented in some studies have demonstrated that sphincter injuries remain up to $91 \%$ in patients with fissures repaired by interrupted side-to-side sutures.,19 Three-year followup results of our patients have not shown any significant continence problems. Biofeedback therapy has been shown to be helpful for patients suffering from gas incontinence and urogenesis problems.

\section{Conclusion}

Physicians should note that sphincter injuries might happen after every delivery. Patients should be informed about the fact that they might experience incontinence problems during the follow-ups. We believe that it is significant to perform surgical intervention before tissue edema develops.

\section{Ethics}

Ethics Committee Approval: The study was approved by the Necmettin Erbakan University Meram Faculty of Medicine Ethics Committee (approval number: 2017/292).

Informed Consent: Informed consent was obtained from all individual participants included in the study.

Peer-review: Externally peer-reviewed.

\section{Authorship Contributions}

Surgical and Medical Practices: M.Ç., M.A.Y., Concept: M.Ç., Design: M.Ç., Data Collection or Processing: M.Ç., Analysis or Interpretation: M.C.., M.A.Y., Literature Search: M.Ç., M.A.Y., Writing: M.Ç., M.A.Y.

Conflict of Interest: No conflict of interest was declared by the authors.

Financial Disclosure: The authors declared that this study received no financial support.

\section{References}

1. Landefeld CS, Bowers BJ, Feld AD, Hartmann KE, Hoffman E, Ingber MJ, et al. National Institutes of Health state-of-the-science conference statement: prevention of fecal and urinary incontinence in adults. Ann Intern Med 2008; $148: 449$.

2. Wald A, Bharucha AE, Cosman BC, Whitehead WE. ACG clinical guideline: management of benign anorectal disorders. Am J Gastroenterol 2014;109:1141

3. Bulut MT, Fekal inkontinans. In: Menteş B, Bulut MT, Alabaz Ö, Leventoğlu S. Anorektal Bölgenin Selim Hastalıkları. 1. Baskı, Ankara, 2011:187-216.
4. Smith LA, Price N, Simonite V, Burns EE. Incidence of and risk factors for perineal trauma: a prospective observational study. BMC Pregnancy Childbirth 2013;7;13:59. doi: 10.1186/1471-2393-13-59.

5. Rogers RG, Leeman LM, Borders N, Qualls C, Fullilove AM, Teaf D, et al. Contribution of these condstage of labourto pelvic floor dysfunction: a prospective cohort comparison of nulliparous women. BJOG 2014;121:1145-1153.

6. Lowder JL, Burrows LJ, Krohn MA, Weber AM. Risk factors for primary and subsequent anal sphincter lacerations: a comparison of cohorts by parity and prior mode of delivery. Am J Obstet Gynecol 2007;196:344.el

7. Jha S, Parker V. Risk factors for recurrent obstetric anal sphincter injury (rOASI): a systematic review and meta-analysis. Int Urogynecol J 2016;27:849-57. Epub 2015 Dec 16.

8. Rosen H, Barrett J, Okby R, Nevo O, Melamed N. Risk factors for obstetric anal sphincter injuries in twin deliveries: a retrospective review. IntUrogynecol J 2016;27:757-62. Epub 2015 Sep 30.

9. Guise JM, Morris C, Osterweil P, Li H, Rosenberg D, Greenlick M. Incidence of fecal incontinence after childbirth. Obstet Gynecol 2007;109:281.

10. Melville JL, Fan MY, Newton K, Fenner D. Fecal incontinence in US women: a population-basedstudy. Am J Obstet Gynecol 2005;193:2071.

11. Nygaard I, Barber MD, Burgio KL, Kenton K, Meikle S, Schaffer J, et al. Pelvic Floor Disorders Network. Prevalence of symptomatic pelvic floor disorders in US women. JAMA 2008;300:1311.

12. Oberwalder M, Connor J, Wexner SD. Meta-analysis to determine the incidence of obstetric anal sphincter damage. Br J Surg 2003;90:13331337.

13. LaCross A, Groff M, Smaldone A. Obstetric anal sphincter injury and anal incontinence following vaginal birth: a systematic review and metaanalysis. J Midwifery Womens Health 2015;60:37-47.

14. Pergialiotis V, Vlachos D, Protopapas A, Pappa K, Vlachos G. Risk factorsfor severe perineal lacerations during childbirth. Int J Gynaecol Obstet 2014;125:6-14.

15. Duggal N, Mercado C, Daniels K, Bujor A, Caughey AB, El-Sayed YY. Antibiotic prophylaxis for prevention of postpartum perineal wound complications: a randomized controlled trial. Obstet Gynecol 2008;111:1268-1273

16. Lewicky-Gaupp C, Leader-Cramer A, Johnson LL, Kenton K, Gossett DR. Wound complications after obstetric anal sphincter injuries. Obstet Gynecol 2015;125:1088-1093.

17. Fernando RJ, Sultan AH, Kettle C, Thakar R. Methods of repair for obstetric anal sphincter injury. Cochrane Database of Systematic Reviews 2013;12: CD002866. DOI: 10.1002/14651858.CD002866.

18. Peirce C, Murphy C, Fitzpatrick M, Cassidy M, Daly L, O'Connell PR, et al. Randomised controlled trial comparing early home biofeedback physiotherapy with pelvic floor exercises for thetreatment of third-degree tears (EBAPT Trial). BJOG 2013;120:1240-1247.

19. Practice Bulletin No. 165: Prevention and Management of Obstetric Lacerations at Vaginal Delivery. American College of Obstetricians and Gynecologists' Committee on Practice Bulletins-Obstetrics. Obstet Gynecol 2016;128:el-el5. 